\title{
Select bibliography on international law until 1945
}

Bernard, Mountague, On the Principle of Non-Intervention: A Lecture Delivered in the Hall of All Souls College, December MDCCCLX (Oxford: J. H. and J. Parker, 1860).

Bluntschli, Johann Caspar, Le droit international codifié (Paris: Librairie de Guillaumin et Cie, 1874, 2nd French edition, translated from the German by M. C. Lardy) [1868].

Bonfils, Henri, Manuel de droit international public (droit des gens) (Paris: Librairie nouvelle de droit et de jurisprudence, 1905, 4th edition by Paul Fauchille) [1894].

Borchard, Edwin M., 'Basic Elements of Diplomatic Protection of Citizens Abroad', American Journal of International Law, 7:3 (1913).

Brierly, J. L., The Law of Nations: An Introduction to the International Law of Peace (Oxford: Clarendon Press, 1936, 2nd edition) [1928].

Calvo, Charles [Carlos], Le droit internationale: théorie et pratique (Paris: Guillaumin et Cie, G. Pedone-Lauriel, 1880, 3rd edition) [1870].

Carnazza Amari, G. [Guiseppe], 'Nouvel exposé du principe de non-intervention', Revue de droit international et de législation comparée, 5 (1873).

Creasy, Sir Edward S., First Platform of International Law (London: John van Voorst, 1876).

Despagnet, Frantz, Cours de droit international public (Paris: L. Larose, 1894).

Engelhardt, Éd. [Édouard Philippe], Le droit d'intervention et la Turquie. Étude historique (Paris: A. Cotillon et Cie, 1880).

Fauchille, Paul, Traité de droit international public (Paris: Rousseau et Cie, 1926, 8th updated and rewritten edition of Bonfil's Manuel de droit international public (droit des gens)) [1877], vol. I, part i.

Fenwick, C. G., 'Intervention: Individual and Collective', American Journal of International Law, 39:4 (1945).

Fiore, Pasquale, Nouveau droit international public suivant les besoins de la civilization moderne (Paris: A. Durant et Pedone-Lauriel, 1885, 2nd edition, translated from the Italian and annotated by Charles Antoine) [1865], vol. I.

Floeckher [Flöcker], Adolph de, De l'intervention en droit international (Paris: A. Pedone, 1896).

Funck-Brentano, Théophile and Albert Sorel, Précis du droit des gens (Paris: Librairie Plon, 1887, 2nd edition) [1877].

Hall, William Edward, A Treatise on International Law (Oxford: Clarendon Press, 1895, 4th edition) [1880].

Halleck, Henry Wager, Halleck's International Law or Rules Regulating the Intercourse of States 
in Peace and War (London: Kegan Paul, Trench, Trubner and Co., 1893, 3rd edition by S. Baker) [1861], vol. I.

Harcourt, William Vernon [pen-name Historicus], Letters by Historicus on Some Questions of International Law. Reprinted from 'The Times' with Considerable Additions (London: Macmillan, 1863).

Heffter, A. W. [August Wilhelm], Le droit international de l'Europe (Berlin: H. W. Muller; Paris: A. Cotillon et Cie, 1883 , 4th French edition, translated from the German by Jules Bergson) [1844]

Hershey, Amos S., 'The Calvo and Drago Doctrines', American Journal of International Law, 1:1 (1907).

Higgins, A. Pearce, Studies in International Law and Relations (Cambridge: Cambridge University Press, 1928).

Hodges, Henry Green, The Doctrine of Intervention (Princeton: Banner Press, 1915).

Holland, Thomas Erskine, Lectures on International Law (London: Sweet and Maxwell, 1933, edited by Thomas Alfred Walker and Wyndham Legh Walker).

Hornung, Joseph, 'Civilisés et barbares', Revue de droit international et de législation comparée, 17 (1885).

Hyde, Charles Cheney, 'Intervention in Theory and in Practice', Illinois Law Review, 6:1 (1911).

Kent, James, Kent's Commentary on International Law (Cambridge: Deighton, Bell, 2nd edition 1878) [1866], extracted and edited by John Thomas Abdy from James Kent, Commentaries on American Law (New York: O.Halsted, 1848) [1826].

Komarovskiy [Kamarowski], Count L. [Leonid], Nachalo nevmeshatel'stva [The Principle of Non-intervention] (Moscow: Universitetskaja Tipografiya, 1874).

Lauterpacht, H. [Hersch], 'Règles générales du droit de la paix', Recueil des cours de l'Académie de droit international, 62 (1937).

Lawrence, T. J. [Thomas Joseph], The Principles of International Law (Boston: D. C. Heath, 1905, 3rd edition, revised) [1895].

Lingelbach, W. E. [William Ezra], 'The Doctrine and Practice of Intervention in Europe', Annals of the Academy of Political and Social Science, 16 (1900).

Lorimer, James, The Institutes of the Law of Nations: A Treatise of the Jural Relations of Separate Political Communities (Edinburgh and London: William Blackwood and Sons, 1883, 1884), vols I, II.

Mamiani, Count [Terenzio], Rights of Nations, or the New Law of European States Applied to the Affairs of Italy (London: W. Jeffs, 1860, translated from the Italian by Roger Acton, and dedicated, by special permission, to Lord John Russell) [1859].

Mandelstam, André, 'La protection des minorités', Recueil des cours de l'Académie de droit international, 1 (1923).

Martens, F. F., Sovremennoe Mezhdunarodnoe Pravo Tsivilizovannykh Narodov [The Contemporary International Law of Civilized Peoples] (St Petersburg: Tipografiya A. Benke, 1904, 5 th revised edition) [1883], vol. I.

Mérignhac, A. [Alexandre], Traité de droit public international (Paris: Librairie générale de droit et de jurisprudence, 1905), part i.

Moore, John Bassett, A Digest of International Law (Washington, DC: Government Printing Office, 1906), vol. VI.

Nys, Ernest, Le droit international: les principles, les théories, les faits (Brussels: M. Weissenbruch, 1912, new edition) [1906], vol. II.

Oppenheim, L. [Lassa F. L.], International Law: A Treatise (London: Longmans, Green and Co., 5 th edition, edited by H. Lauterpacht, 1937) [1905], vol. I. 
Phillimore, Sir Robert, Commentaries upon International Law (London: Butterworth, 1879, 3rd edition) [1854], vol. I.

Pillet, Antoine, 'Le droit international public', Revue générale de droit international public, 1 (1894).

Politis, Nicolas, La morale internationale (Paris: Bibliothèque Brentano's, 1944).

Potter, Pitman B., 'L'intervention en droit international moderne', Recueil des cours de l'Académie de droit international, 32 (1930).

Pradier-Fodéré, Paul Louis, Traité de droit international public européen et américain, suivant le progrès de la science et de la pratique contemporaines (Paris: A. Durand et Pedone-Lauriel, 1885), vol. I.

Renault, Louis, Introduction à l'étude du droit international (Paris: L. Larose, 1879).

Rivier, Alphonse, Principes du droit des gens (Paris: Librairie nouvelle de droit et de jurisprudence, 1896).

Rolin-Jaequemyns, Gustave, 'Note sur la théorie du droit d'intervention, à propos d'une lettre de M. le professeur Arntz', Revue de droit international et de législation comparée, 8 (1876).

Rougier, Antoine, 'La théorie de l'intervention d'humanité', Revue générale de droit international public, 17 (1910).

Séfériadès, Stélio, 'Principes généraux du droit international de la paix', Recueil des cours de l'Académie de droit international, 34 (1930).

Senior, Nassau William, 'Art.I-1. Histoire du Progrès du Droit des Gens depuis la Paix de Westphalies jusqu'au Congrès de Vienne. Par Henry Wheaton', Edinburgh Review, 77:156 (1843).

Stowell, Ellery C., Intervention in International Law (Washington, DC: John Byrne, 1921).

Strupp, Karl, 'Les règles générales du droit de la paix', Recueil des cours de l'Académie de droit international, 47 (1934).

Walker, Thomas Alfred, A Manual of Public International Law (Cambridge: Cambridge University Press, 1895).

Westlake, John, International Law, Part I: Peace (Cambridge: Cambridge University Press, 1904).

Wheaton, Henry, Elements of International Law: With a Sketch of the History of the Science (Philadelphia: Carey, Lea and Blanchard, 1836).

Wilson, George Grafton, International Law (New York: Silver, Burdett, 1922, 8th edition) [1901].

Winfield, P. H., 'The History of Intervention in International Law', British Year Book of International Law, 3 (1922-23).

Woolsey, Theodore D., Introduction to the Study of International Law (London: Sampson Low, Marston, Searle and Rivington, 1879, 5th edition revised and enlarged) [1860].

Woolsey, Theodore Salisbury, American Foreign Policy (New York: Century, 1898). 